\title{
Molecular Identification of Pseudomonas syringae (Savastoni) pv. Phaseolicola in Mung Bean (Vigna radiata L. Wilczek) Seeds Grown in Rajasthan State, India
}

\author{
Surabhi Chaturvedi*, Kailash Agrawal, Sanchita Kulshrestha and Avinash Narayan
}

Lab no. 10, Department of Botany, University of Rajasthan, Jaipur, 302004, Rajasthan, India

*Corresponding author

\begin{abstract}
A B S T R A C T
Present study was designed to aim isolation and identification of halo blight bacterium;

Keywords

16s rRNA sequencing, Halo blight,

Pseudomonas syringae (savastoni) pv. phaseolicola

\section{Article Info}

Accepted:

15 October 2018

Available Online:

10 November 2018

Pseudomonas syringae (savastoni) pv. phaseolicola (Psp) in seed lots of mung bean collected from fields of various districts of Rajasthan state, India. A heavy incidence of the pathogen was recorded in seed lots from Ajmer (82.5\%), Nagaur (78.88\%), Ganganagar (70\%), Hanumangarh (76.34\%) and Jalore (73.33\%) districts. Total 33 isolates of Psp were isolated on semi selective medium MSP from the seeds of mungbean grown in Rajasthan state. These 33 isolates with typical morphological and biochemical characteristics of Psp were further examined through PCR amplification and sequencing of 16s rRNA gene. These isolates were characterized on the basis of colony characteristics, biochemical methods, pathogenicity test and further on the basis of $16 \mathrm{~s}$ rRNA sequencing. The fragment of $16 \mathrm{~s}$ rRNA gene of approximately $1.5 \mathrm{~kb}$ size was obtained from these isolates and was amplified using universal primers; 8F and 1492R and identified as Pseudomonas syringae (savastoni) pv. phaseolicola when compared with database available on NCBI. A phylogenetic tree was constructed based on the 16s rRNA sequence using neighbour joining method (NCBI).
\end{abstract}

\section{Introduction}

Mung bean is popular in developing countries as a rich source of vitamins, minerals and proteins (Tang et al., 2014; Jayaprakash Priya et al., 2012; Mubarak, 2005). AVDRC in its report in 2009 declared it as valuable crop as like other legumes. It converts nitrogen from the air into helpful compounds that contribute to plant growth and soil fertility and has contributed to improving rural household income, expanding employment opportunities, diversifying diets, increasing nutritional security, and enhancing soil fertility in Asia (Jayaprakash Priya et al., 2012). It suffers from a large number of bacterial diseases caused by various members of pseudomonadae.

Halo blight, caused by Pseudomonas savastoni pv. phaseolicola has been identified as a big threat for bean production and to 
pockets of poor farmers. Development of Halo blight is greatly favoured by cold and humid climate; this is the cause of its heavy prevalence in countries like India (Schwartz et al., 2005). It is transmitted through contaminated seeds (Schwartz, 1989), this phytopathogen host a variety of beans including Vigna radiata to Vigna mungo, Vigna ungulata, Phaseolus vulgaris and $P$. Lunata (Ishimaru et al., 2005). Water - soaked lacerations encircled by a halo is developed at optimum temperature ranging $18-20^{\circ} \mathrm{C}$ temperature (Donmez et al., 2013; Arnold et al., 2011; Harveson and Schwartz, 2007). The bacterium resides in seeds and waits till germination for its own growth and disease development (Burkholder, 1930; Arnold et al., 2011).

It has been recognized as an important disease causing massive losses to yield worldwide but it is has more devastating effects in developing countries like India. Some countries like US have directed to destroy the entire crop and seed lots if found infected with this pathogen (Prosen et al., 1993).

\section{Materials and Methods}

\section{Field survey and collection of samples}

For sample collection farmer's fields were visited and total of 151 seed samples were collected from various districts of Rajasthan state. Other source of inoculums such as infected leaves, stems and pods were collected from fields and also from potted plants in the green house.

The field seed samples were characterized as bold discoloured, moderately discoloured and healthy looking on the basis of external deformation of seed indicating presence of infection viz. appearance of discolouration of cotyledon, on and around hilum and wrinkles on seed coat by dry seed inspection.
Isolation, purification, identification and characterization

The seeds of first two categories were surface sterilized with $2 \% \mathrm{NaOCl}$ and directly plated on nutrient agar (NA) and incubated at $25 \pm 2^{\circ} \mathrm{C}$ for 2-3 days for development of bacterial colonies. Clusters with typical morphological features of Psp were further purified on NA. Serial dilution and spreading was used for further purification of single colony. Purified colonies were subjected to various biochemical tests for their identification (Lelliot and Stead, 1987; Harley-Prescott, 2002; Aneja, 2003; ISTA 2008, 2010). Isolates were also tested for utilization of mannitol, m-inositol, erythritol and sorbitol in Hellmers broth (Jansing and Rudolph, 1990), utilization of D-tartrate, L-lactate and Ltartarate in Ayer's solid medium (Schaad, 1988). Suspected colonies were isolated, purified and characterized by biochemical and physiological tests. The colonies suspecting to be Psp were grown on semi-selective medium MSP (modified sucrose peptone agar medium).

\section{Pathogenicity and host test}

Pathogenicity test was done by injecting suspension of $24 \mathrm{hrs}$ old culture of the pathogen in the mid rib of leaves (Vigna radiate, $V$. mungo, $V$. Ungulate and $P$. vulgaris) with the help of a sterilized needle. For the development of typical symptoms of halo blight i.e. water soaked necrotic lesions on detached leaves of tobacco and host plants, the leaves were then incubated at optimum temperature of $25 \pm 2^{\circ} \mathrm{C}$ for 2-3 days for development of symptoms (Saettler et al., 1989).

\section{Molecular characterization}

After biochemical characterization the isolates were subjected to molecular characterization. 
For its molecular characterization DNA was extracted from fresh bacterial culture and amplified using F8 (5'-AGT TTG ATC CTG GCT CAG-3') and R1492 (5'-ACC TTG TTA CGA CTT-3') primers for forward and reverse sequences respectively which are specific for bacterial 16s rDNA (Galkiewicz and Kellogg, 2008; Gutell et al., 1994; Woese, 1987). The amplified PCR product was electrophoresed for evaluating its purity and concentration. The DNA fragment $(1.5 \mathrm{~kb})$ was excised and eluted from gel by using 1\%TAE buffer (Murray et al., 1994). This purified product was sequenced at Xcelris genomics, Bangalore.

The sequences obtained were aligned with reference sequences available on Genebank database NCBI and a phylogenetic tree was made using tools available on the website.

\section{Results and Discussion}

The disease caused by Pseudomonas savastoni pv. phaseolicola (Halo blight) has been declared as a big threat to mung bean as it cause a big hazard to the production of this legume. In the present study all seed lots collected from various fields of Rajasthan state has been screened for the presence of this pathogen and 16s rRNA sequencing has been employed as an identification tool for it. A total of 151 seed samples were collected and categorised in bold discoloured, moderately discoloured and healthy looking seeds and examined for manifestation and incidence of Psp. Higher incidence of pathogen in seed lots was observed in various districts namely Ajmer (82.5\%), Nagaur (78.88\%), Ganganagar (70\%), Hanumangarh (76.34\%) and Jalore (73.33\%).

The colonies of Psp were creamy or white in colour with circular shape on NA whereas the colony characteristics were raised, globose, shining with light yellow pigmentation and less dense centre when grown on semiselective medium MSP (Popovic et al., 2012; ISTA, 2010; ISTA 2008, Kurowski and Remeeus, 2008; Jansing and Rudolph, 1996; Jansing and Rudolph, 1990; Mohan and Schaad, 1987). Mustansar and colleagues (2015) also found these biochemical characteristics useful for characterization and identification of Xanthomonas axonopodis pv. citri.

In this study a total of 63 bacterial colonies were isolated and purified from seeds of mung bean and results of their biochemical characteristics were compared and analysed with earlier reports (Arnold et al.,2011) and found that the 33 isolates were levan + , - for oxidase, not able to utilize sugars such as mannintol, sorbitol and inositol as sole carbon source whereas some strains were able to utilize mannintol (Fourie, 2002) indicating similarity with other strains of Psp identified in earlier studies (Murillo et al., 2010; Harveson et al., 2007; Taylor et al., 1996). The development of water- soaked lacerations on leaves, pods, stems and petioles in pot experiment as well as pathogenicity test confirmed the isolates to be the Psp (Anonymous, 2008).

In DNA isolation bacterial genomic DNA of approximate $33 \mathrm{~kb}$ size was obtained for the suspected bacterial isolates. On PCR amplification of $16 \mathrm{~s} \mathrm{r}$-gene $1.5 \mathrm{~kb}$ product was obtained for this internal sequence of all isolates analysed. On the basis of ARDRA pattern, the eight selective phytopathogenic bacterial strains were grouped in three; The group A contained three bacterial strains named VR-X-2011-09, VR-X-2012-16 and VR-X-2013-1 9 and similarly group B contained bacterial isolates VR-P-2011-19, VR-P-2012-11 and VR-P-2013-07 and the isolates from group $B$ were identified as Pseudomonas savastoni pv. Phaseolicola on the basis of $16 \mathrm{~S}$ rRNA gene sequencing. 
Fig.1 Molecular characterization of the isolated bacterial pathogens of mungbean
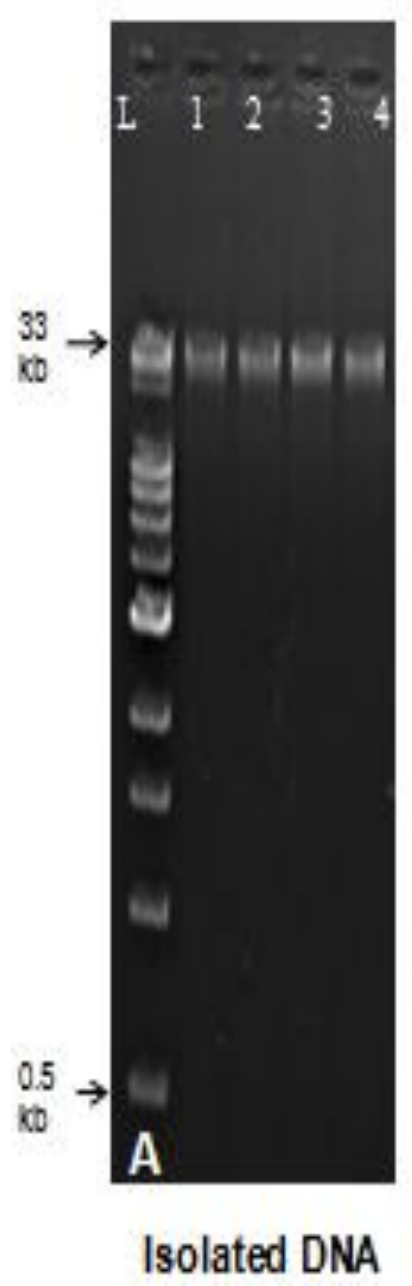
(size $33 \mathrm{~kb}$ )

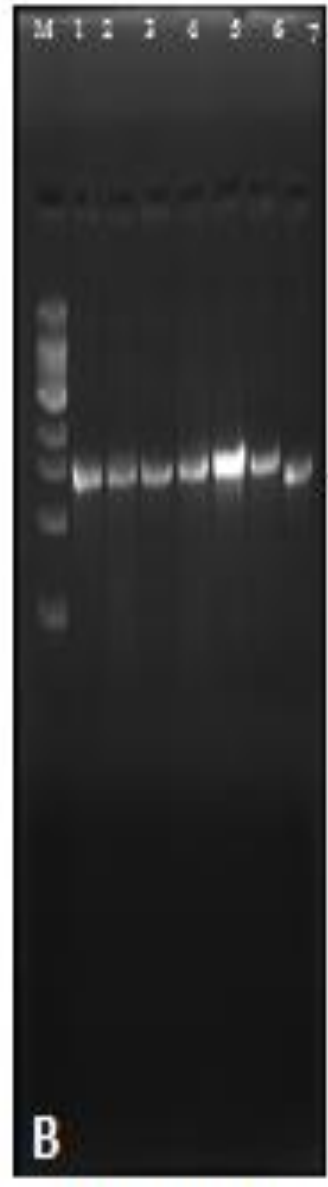

PCR-amplified 16s rDNA (size $1.5 \mathrm{~kb})$

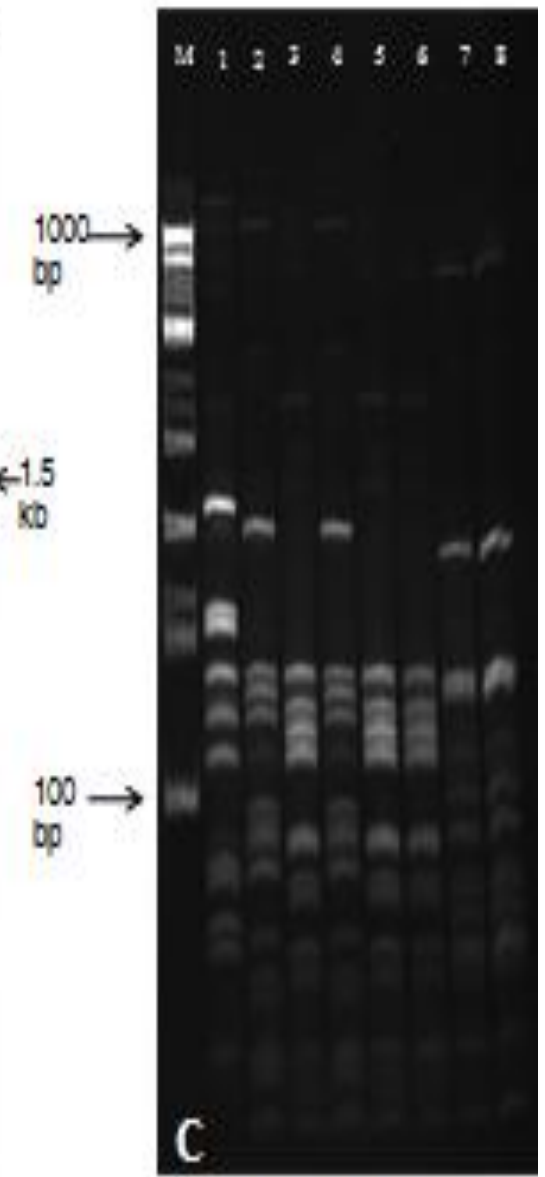

\section{ARDRA profile of 16S rDNA of selective phyto- pathogenic bacteria}

Agarose gel electrophoresis of isolated bacterial genomic DNA

Lane 1: DNA ladder of 33kb

Lane 2-8: DNA isolated with approx $33 \mathrm{~kb}$ in size.

Agarose gel electrophoresis of PCR-amplified 16S rDNA

Lane 1: DNA ladder of $1 \mathrm{~kb}$.

Lanes 2, 3: not reported in this study.

Lanes 4, 5: P. savastoni pv. phaseolicola.

Lane 6-8: Other non-pathogenic bacteria

ARDRA profiles of $16 \mathrm{~S}$ rDNA

Lane 1: Molecular size standards;

Lanes 2, 3\& 5: not reported in this study

Lanes 4, $6 \&$ 7: RFLP profiles corresponding to atypical isolates of Psp

Lanes 8 \& 9: Other non-pathogenic bacteria 
Fig.2 Dendrogram for the phylogenetic relationships of Pseudomonas savastoni pv. Phaeolicola strain among closely related species based on the sequences of the 16s rDNA region

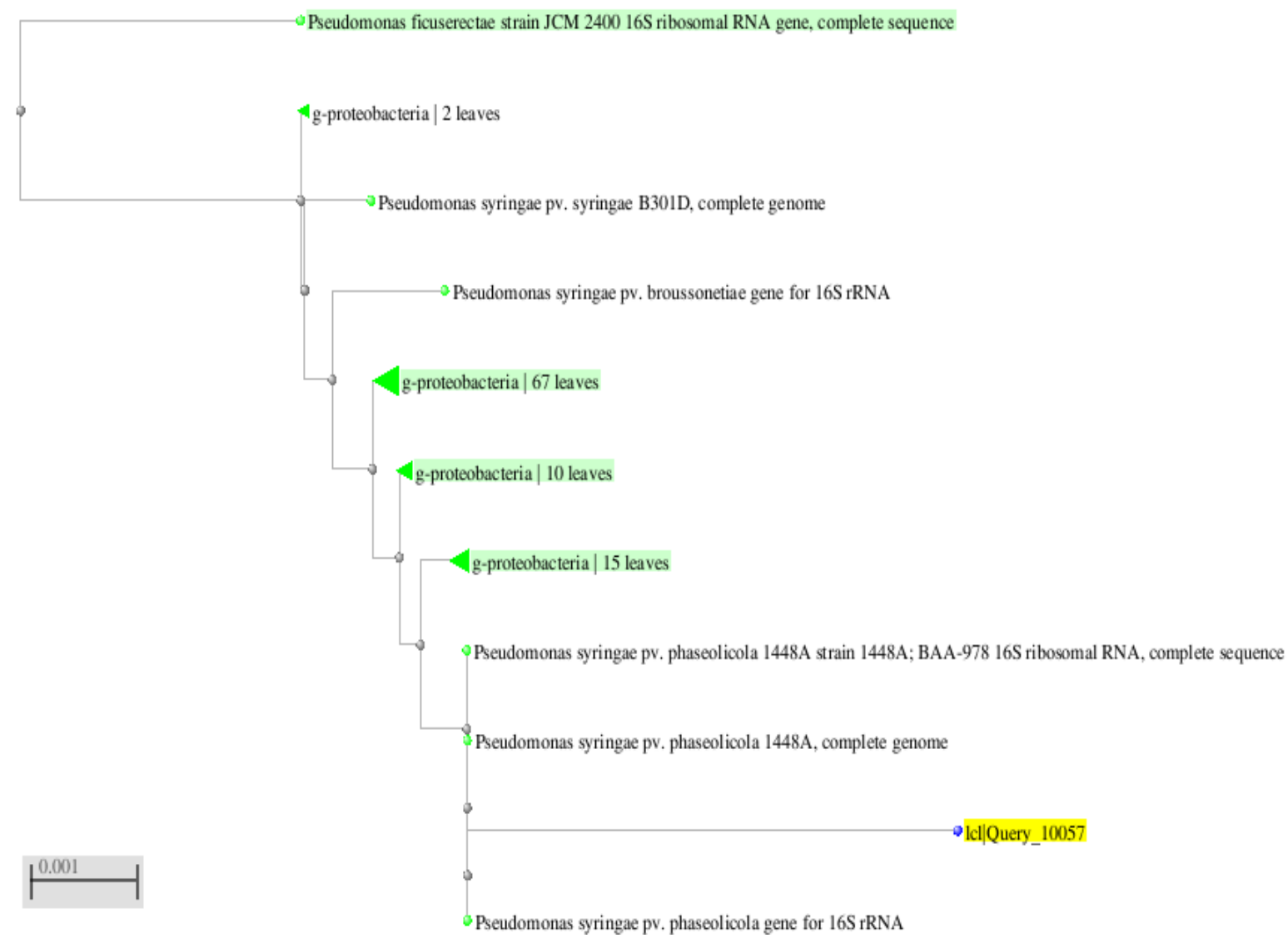

The sequences obtained for16s rDNA were aligned with already available sequences on NCBI database and were found to show phylogenetic similarity with Pseudomonas savastoni pv. Phaseolicola strain (Fig. 1). These sequences have been submitted to NCBI database with gene bank ac. nos. KT283578 to Psp strain. The phylogenetic trees constructed using NCBI database also showed their closeness with other related strains (Fig. 2).

It is reported that Peerajade and colleagues (2017) also found sequencing of 16S rRNA and gyrB gene for identification of bacterial blight pathogen $X$. axonopodis pv. punicae in pomegranate. Shoeib and colleagues (2017) also utilized 16s rRNA gene sequence to identify thirty one isolates of the enterobacterium Erwinia amylovora; the causal agent of the fire blight disease collected from different locations in Egypt and Germany. Importance of 16s rRNA gene for identification of pathogenic and nonpathogenic bacterial species have been reviewed by various researchers (Sharma et al., 2017).

\section{Acknowledgements}

The authors express their gratitude to the DST, Rajasthan, India for providing financial assistance for this work.

\section{References}

Agarwal, P.C., Mortenson, C.N. and Mathur, S.B. 1989. Seed-borne diseases and 
seed health testing of rice. Technical Bull. No. 3, Phytopath. Papers No. 30. Danish Govt. institute of Seed Pathology for Developing Countries (DGISP), Copenhegan and CAB International Mycological Institute, Kew (CMI) UK. pp 106.

Aneja, K.R. 2003.Experiments in Microbiology, Plant Pathology and Biotechnology. $4^{\text {th }}$ edition. New Age International. pp. 607.

Anonymous, 2008. Halo blight in mungbean pathogen, hosts, infection, crop impact, management and future genetics and breeding options http://www.grdc.com. $\mathrm{au} /$ ResearchandDevelopment/

Anonymous. 2008. Seed Health Testing Methods; 7-023: Detection of Pseudomonas savastanoipv. phaseolicola on Phaseolus vulgaris. International Rules for Seed Testing (ISTA), Bassersdorf, Switzerland.

Arnold, D. L., Lovell, H. C., Jackson, R. W., and Mansfield, J. W. 2011. Pseudomonas syringaepv. phaseolicola: From 'has bean' to supermodel. Mol. Plant Pathol. 12:617-627.

AVRDC, 2009.AVRDC Vegetable Genetic Resources Information System, http://203.64.245.173/avgris >.

AVRDC. 2012. Mung bean. Asian Vegetable Research and Development Center The World vegetation center. http://www.avrdc.org/index.php?id=416 \&nocache $=1 \&$ swordlist[]=bean

Burkholder, W.H. (1930) The bacterial diseases of the bean: a comparative study. Memoirs, Cornell Univ. Agric. Exp Station, 127, 1-88

Buruchara, R., Mukankusi, C. and Ampofo, K. 2010. Bean disease and pest identification and management. Centro Internacional de Agricultura Tropical (CIAT), International Center for Tropical Agriculture, Kampala, Uganda
Cowan, S.T. 1974. Manual for the Identification of Medical Bacteria. Cambridge Univ. Press, Great Britain. $238 \mathrm{p}$.

Donmez, M.F., Sahin, F. And Elkoca, E. 2013. Identification of bean genotypes from turkey resistance to common bacterial blight and halo blight diseases. Acta Sci. Pol., Hortorum Cultus 12(4): 139-151.

Fourie, D. 2002. Distribution and severity of bacterial diseases on dry beans (Phaseolus vulgaris L.) in South Africa. J. Phytopathol. 150, 220-226.

Goszczynska, T., Serfontein, J.J. and Serfontein, S. 2000. Introduction to Practical Phytobacteriology, A manual of phytobacteriology. Bacterial disease unit, ARC- Plant Protection Research Institute, Pertoria, South Africa. SAFRINET. pp. 83.

Gutell RR, Larsen N and Woese CR. Lessons from an evolving rRNA: $16 \mathrm{~S}$ and $23 \mathrm{~S}$ rRNA structures from a comparative perspective. Microbiol Rev 1994, 58: $10-26$.

Harley-Prescott. 2002. Laboratory Exercises in Microbiology, $5^{\text {th }}$ edition. The McGraw- Hill Companies. pp. 466.

Harveson, R. M., and Schwartz, H. F. 2007.Bacterial diseases of dry edible beans in the central high plains. Online. Plant Health Progress doi:10.1094/ PHP2007012501DG.

Hildebrand, D.C. and Schroth, M.N. 1972.Identification of fluorescent Pseudomonas. In: proceedings of the $3^{\text {rd }}$ International conference on plant pathogenic bacteria, Wageningen. Centre for Agri. Publishing and Documentaion: 281-287.

Ishimaru, C., Mohan, S. K., and Franc, G. D. 2005. Halo blight.in: Compendium of Bean Diseases. H. F. Schwartz, J. R. Steadman, R. Hall, and R. L. Forster, 
eds. American Phytopathological Society, St. Paul, MN.

Jansing, H. and Rudolph, K. 1990. A sensitive and quick test for determination of bean seed infestation by Pseudomonas syringaepv. phaseolicola. Z PflanzenkrPflanzenschutz 97, 42-55.

Jansing, H. and Rudolph, K. 1996. Pseudomonas syringaepv. phaseolicola: ISTA Handbook on Seed Health Testing. International Seed Testing Association, Zurich, Switzerland. (Working Sheet, 66).

Jaya PrakashPriya, A., YaminiSudhaLakshmi, G., FouziaBanu, Gopalakrishnan, S., Dhanalakshmi, P., Sagadevan, E., Manimaran, A and Arumugam, P. 2012. Phytochemical screening and antibacterial activity of Vigna radiata L. Against bacterial pathogens involved in food spoilage and food borne diseases. J. Acad. Indus. Res. 1(6): 355-359.

Klement, Z. 1963. Rapid detection and the pathogenicity of phytopathogenic Pseudomonads.Nature. 199: 299-300.

Kovac's, N. 1956. Identification of Pseudomonas pyocyanea: The oxidase reaction. Nature, London. 178: 703.

Kurowski, C. and Remeeus, P.M. 2008. Detection of Pseudomonas savastanoipv. phaseolicolaon Phaseolus vulgaris. International Seed Testing Association, Bassersdorf, Switzerland. (International Rules for Seed Testing, 7-023).

Lelliott, R., A. and Stead, D., E. 1987. Methods for the diagnosis of bacterial diseases of plants. In Methods in Plant Pathology, Vol. 2. Blackwell Scientific Publication, Oxford, London. pp 216.

Mohan, S.K. and Schaad, N.W. 1987. An improved agar plating assay for detecting Pseudomonas syringaepv. Syringae and P. s. pv. Phaseolicola in contaminated bean seed. Phytopathology 77: 1390-1395.
Mortensen, C., N., 1994a. Seed health testing for bacterial pathogens. Danish Govt. Institute of Seed Pathology for developing Countries (DGISP), Copenhagen, Denmark. pp 68.

Mortensen, C., N., 1994b. Seed bacteriology laboratory guide. Danish Govt. Institute of Seed Pathology for developing Countries (DGISP), Copenhagen, Denmark. pp 102.

Mubark, A.E. 2005.Nutritional composition and antinutritional factors of mung bean seeds (Phaseolusaureus) as affected by some home traditional processes. Food Chem. 89: 489-495.

Murillo, J., Bardaji, L. and Führer, E.2010. La grasa de lasjudías, causadapor la bacteria Pseudomonas syringaepv. phaseolicola. Phytoma, 224, 27-32.

Murray, R. G. E., Doetsch, R. N., \& Robinow, C. F. (1994).Determinative and cytological light microscopy. Methods for General and Molecular Bacteriology, 1, 22-41.

Peerajade D.A., Moger N. and Patil H.B., 2017. Studies on Variability, Identification of Xanthomonas axonopodis $p v$. punicae Isolates and Screening of Gamma $(\gamma)$ Irradiated Seed Derived Progenies and Germplasms of Pomegranate. Int.J.Curr.Microbiol. App.Sci (2017) 6(8): 2987-3002

Popovic T, Milovanovic P, Aleksic G, Gavrilovic V, Starovic M, Vasic M, Balaz, J. 2012. Application of semiselective mediums in routine diagnostic testing of Pseudomonas savastanoipv. phaseolicola on common bean seeds. Scientia Agricola, 69(4):265-270. http://www.scielo.br/sa

Prosen, D., Hatziloukas, E., Schaad, N.W. and Panopoulos, N.J. 1993. Specific detection of Pseudomonas syringae pv. Phaseolicola DNA in bean seed by polymerase chain reaction-based 
amplification of a phaseolotoxin gene region. Phytopathology, 83, 965-970.

Rico A, Erdoza in M, Ortiz-Barredo A, Ruiz de Galarreta JI, Murillo J. 2006.Short communication. Detection by multiplex PCR and characterization of nontoxigenic strains of Pseudomonas syringae $p v$. phaseolicola from different places in Spain. Spanish Journal of Agricultural Research. 4(3):261-7.

Saettler, A., W., Schaad, N., W. and Roth, D., A., 1989. Detection of bacteria in seed (Ed.) APS Press (The American Phytopathological Society), St. Paul, Minnesota. pp 122.

Schaad, N. 1988. Laboratory Guide for Identification of Plant Pathogenic Bacteria, 2nd edn. St Paul, MN: APS Press.

Schwartz H.F., 1989. Halo blight. In: Bean production problems in the tropics (Schwartz H.F., Pastor-Corrales M.A., eds.). International Center of Tropical Agriculture, CIAT, Cali, Colombia, pp. 285-301.

Schwartz, H. F., Franc, G. D., Hanson, L. E, and Harveson, R. M. 2005.Disease management.in: Dry Bean Production and Pest Management. H. F. Schwartz, M. A. Brick, R. M. Harveson, and G. D. Franc, (eds). Colorado State Univ., Cort Collins, $\mathrm{CO}$.

Sharma P., Bora L.C., Puzari K.C., Baruah A.M., Baruah R., Talukdar K., Kataky L. and Phukan A., 2017. Review on Bacterial Blight of Rice Caused by Xanthomonas oryzae pv. oryzae: Different Management Approaches and
Role of Pseudomonas fluorescens As A Potential Biocontrol Agent. Int.J.Curr. Microbiol.App.Sci (2017) 6(3): 9821005

Shoeib AA, Ashmawy NA, Hammad SM, Hafez EE (2017) Molecular and Biological Identification of Erwinia amylovora Egyptian Isolates Compared with Other German Strains. J Plant Physiol Pathol 5:1.

Tang, D., Dong, Y., Ren H., Li, L. and He, C. 2014.A review of phytochemistry, metabolite changes, and medicinal uses of the common food mung bean and its sprouts (Vigna radiata). Chemistry Central Journal, 8:4.

Taylor, J.D., Teverson, D.M., Allen, D.J. and Pastor-Corrales, M.A. 1996. Identification and origin of races of Pseudomonas syringae pv. Phaseolicola from Africa and other bean growing areas. Plant Pathol.45, 469-478.

Verma A. K., Arora P. and Agrawal K., 2016. Incidence of bacterial blight pathogen Pseudomonas syringae pv. pisi in pea seeds grown in Rajasthan, India. Legume Research, 39 (6) 2016: 1034 1037

Woese CR. Bacterial evolution. Microbiol Rev 1987, 51: 221-271.

Mubeen M., Hafiz M. I. Arshad, Iftikhar Y., Irfan Ullah M. and Bilqees I., 2015. Bio-chemical characterization of Xanthomonas axonopodis pv. citri: a gram negative bacterium causing citrus canker. Int. J. Sci. Nature. VOL.6 (2) 2015: 151-154

\section{How to cite this article:}

Surabhi Chaturvedi, Kailash Agrawal, Sanchita Kulshrestha and Avinash Narayan. 2018. Molecular Identification of Pseudomonas syringae (Savastoni) pv. Phaseolicola in Mung Bean (Vigna radiata L. Wilczek) Seeds Grown in Rajasthan State, India. Int.J.Curr.Microbiol.App.Sci. 7(11): 1859-1866. doi: https://doi.org/10.20546/ijcmas.2018.711.210 